\title{
IMPLIKASI TANGGUNG JAWAB SOSIAL DAN LINGKUNGAN TERKAIT POTENSI DUGAAN KEJAHATAN KORPORASI: STUDI CONTENT ANALYSIS PADA PT LAPINDO BRANTAS INC.
}

\author{
Waya Muthia Wardhani \\ Departemen Akuntansi, Fakultas Bisnis dan Ekonomika Universitas Surabaya \\ wayamuthia@gmail.com \\ Fidelis Arastyo Andono \\ Departemen Akuntansi, Fakultas Bisnis dan Ekonomika Universitas Surabaya \\ fidelis@staff.ubaya.ac.id
}

\begin{abstract}
Management actions, which are supported by the implementation of corporate governance, is crucial in the decision making for any corporate actions. But in many occasions, the management took the decision to neglect the environment and social responsibility and set aside long-term goals of the company. On May 29, 2006 in the drilling area of PT Lapindo Brantas Inc. (Lapindo) located in Porong, Sidoarjo, an incident in which is one of the drilling well releases gas and mud. This case happened because the company allegedly shirking the implementation of social and environmental responsibility of theirs. The purpose of this study was to analyze the implementation of the activities of social and environmental responsibility of a company, and then connect the involvement of social environmental responsibility with the potential of alleged corporate crime. Using the content analysis method, the results showed that social and environmental responsibility of a company is very important to be implemented. In addition, management as manager of the company must always run actions guided by the principles of good governance. If the principles of good governance are not implemented by management, corporate actions whether intentional or not, will be more vulnerable and has the potential to intersect with corporate crime.
\end{abstract}

Keywords: social and environmental responsibility, corporate crime, the principles of good governance

ABSTRAK : Tindakan manajemen, yang didukung oleh penerapan tata kelola perusahaan, sangat penting dalam pengambilan keputusan untuk tindakan korporasi. Namun dalam banyak kesempatan, manajemen mengambil keputusan untuk mengabaikan lingkungan dan tanggung jawab sosial dan menyisihkan tujuan jangka panjang perusahaan. Pada tanggal 29 Mei $2006 \mathrm{di}$ area pengeboran PT Lapindo Brantas Inc (Lapindo) yang berada di Porong, Sidoarjo, sebuah kejadian di mana salah satu sumur pengeboran melepaskan gas dan lumpur. Hal ini terjadi karena perusahaan tersebut diduga mengelak dari pelaksanaan tanggung jawab sosial dan lingkungannya. Tujuan dari penelitian ini adalah untuk menganalisis pelaksanaan kegiatan tanggung jawab sosial dan lingkungan suatu perusahaan, dan kemudian menghubungkan keterlibatan tanggung jawab lingkungan sosial dengan potensi dugaan tindak pidana perusahaan. Dengan menggunakan metode analisis isi, hasil penelitian menunjukkan bahwa tanggung jawab sosial dan lingkungan perusahaan sangat penting untuk diimplementasikan. Selain itu, manajemen sebagai manajer perusahaan harus selalu menjalankan tindakan yang dipandu oleh prinsip-prinsip good governance. Jika prinsip good governance tidak dilaksanakan oleh manajemen, tindakan korporasi apakah disengaja atau tidak, akan lebih rentan dan berpotensi berpotongan dengan corporate crime.

Kata kunci: tanggung jawab sosial dan lingkungan, corporate crime, prinsip good governance 


\section{Pendahuluan}

Dewasa ini perusahaan atau korporasi sedang menjadi sorotan berbagai pihak, baik itu korporasi nasional maupun luar negeri. Baik itu perusahaan yang bergerak dalam industri minyak dan gas (migas) maupun non migas. Korporasi yang bergerak dalam industri migas seringkali menjadi pembicaraan dikarenakan setiap keputusan dalam operasional maupun tindak-tanduk perusahaan sangatlah berdampak dan mempengaruhi kelangsungan kehidupan bagi para stakeholder di sekitarnya. Tidak terkecuali bagi PT Lapindo Brantas Inc.(Lapindo) dan British Petroleum plc.(BP). British Petroleum plc. merupakan perusahaan minyak dan gas bumi ternama yang berasal dari Inggris. Berdasarkan data dari The Richest, $\mathrm{BP}$ sebagai perusahaan dengan wilayah operasi di berbagai Negara, dari Timur Tengah hingga Alaska, menempati urutan ke-6 dalam kategori 10 perusahaan minyak raksasa di dunia (Sukmana,2014). Produksi minyak BP sebanyak 4,1 juta barrel per hari menempatkan BP pada posisi urutan ke6 dalam kategori 25 perusahaan migas terbesar di dunia berdasarkan data yang dilansir oleh majalah Forbes (Kurniawan,2013). Begitu juga halnya dengan Lapindo, yang menjadi banyak sorotan karena merupakan salah satu anak perusahaan dari Grup Bakrie, yang terkenal akan bisnisnya yang menggurita.

Pada saat ini, maksimalisasi profit saja tidak cukup untuk memastikan bahwa korporasi akan berdiri selamanya dalam dunia bisnis. Seperti yang diungkapkan oleh Mahajan (2011) dalam Fontaine (2013) bahwa saat ini terdapat persepsi yang berkembang di antara perusahaanperusahaan bahwa bisnis berkelanjutan yang sukses dan nilai pemegang saham tidak dapat dicapai hanya melalui memaksimalkan keuntungan jangka pendek, melainkan melalui perilaku yang berorientasi pasar dan perilaku yang bertanggung jawab. Perusahaan menyadari bahwa mereka dapat berkontribusi untuk pembangunan berkelanjutan dengan mengelola operasi mereka sedemikian rupa untuk meningkatkan pertumbuhan ekonomi dan meningkatkan daya saing sekaligus menjamin perlindungan lingkungan dan mempromosikan tanggung jawab sosial (Fontaine,2013).

Menyadari akan berkembangnya prinsip bisnis yang berkelanjutan, Lapindo mengimplementasikan tanggung jawab sosial dalam operasional perusahaan. Lapindo menggunakan standar HSE sebagai kerangka pelaksanaan tanggung jawab sosial lingkungan, yang diimplementasikan dalam bentuk pengelolaan limbah dan program pengembangan masyarakat (Lapindo Brantas Inc.,2016).

Tidak selamanya pelaksanaan tanggung jawab sosial dan lingkungan akan berjalan mulus tanpa hambatan. Terkadang, berbagai hal dapat mempengaruhi dan mengakibatkan keputusan yang diambil menjadi tidak berpedoman pada implementasi tanggung jawab sosial lingkungan yang berorientasi jangka panjang.Keputusan yang tidak berpedoman pada kepentingan jangka panjang dapat menyebabkan praktik tanggung jawab sosial dan lingkungan perusahaan tidak dijalankan dengan baik.Sudah sangat banyak kasus tanggung jawab sosial lingkungan yang menimpa berbagai perusahaan terkemuka, khususnya di bidang pertambangan dan migas yang ada di dalam maupun luar negeri.

Salah satunya yaitu peristiwa yang dialami oleh Exxon, dimana pada tanggal 24 Maret 1989, kapal tanker minyak Exxon Valdez kandas di Bligh Reef di Prince William Sound di lepas pantai Alaska. Kejadian tersebut adalah salah satu tumpahan minyak terburuk dalam sejarah pada saat itu, hampir 11 juta galon minyak bocor, dengan perkiraan ukuran sebesar 17 kolam renang olimpiade. Tumpahan minyak tersebut masuk kedalam lautan murni 
dan akhirnya lebih dari 1.300 mil dari garis pantai dilapisi dengan minyak kotor berwarna hitam (Whitman,2015). Sedangkan di Indonesia, kejadian dugaan pencemaran lingkungan menimpa PT Newmont Minahasa Raya (PT NMR) pada tahun 2004, dimana PT NMR dilaporkan oleh sekumpulan warga Teluk Buyat yang mengalami masalah kesehatan karena diduga keracunan limbah merkuri. Diduga, merkuri yang terkandung pada air Teluk Buyat berasal dari pembuangan limbah tambang (tailing) yang dibuang PT NMR (detikNews,2004).Kasus ini sempat menghebohkan masyarakat karena keluhan kesehatan yang diderita warga kerap disamakan dengan penyakit Minamata yang ada di Jepang.

Kejadian

pencemaran lingkungan sebagai akibat dari pelaksanaan tanggung jawab sosial dan lingkungan yang kurang baik juga dialami oleh BP. Pada tanggal 20 April 2010, terjadi tumpahan minyak mentah di perairan Teluk Meksiko dan meledaknya kilang minyak (rig) Deepwater Horizon milik British Petroleum plc., yang membuat komitmen dan praktik tanggung jawab sosial lingkungan BP menjadi dipertanyakan. Kejadian ini disebutsebut sebagai tumpahan minyak terburuk sepanjang sejarah di Amerika Serikat, serta mengakibatkan terdapat 11 korban jiwa (Barrett,2014).

Akibat dari insiden di Teluk Meksiko, lingkungan dan makhluk hidup juga turut merasakan imbasnya. Beberapa diantaranya yaitu, kematian mamalia laut sudah setingkat kematian 5000 individu, dan hampir 1 juta burung laut pesisir dan lepas pantai diperkirakan telah mati sebagai akibat dari tumpahan minyak. Selain itu, industri perikanan komersial Teluk Meksiko diperkirakan telah mengalami kerugian \$247 miliar akibat dari penutupan wilayah pemancingan hasil laut, setelah terjadinya tumpahan minyak (NRDC, 2015). Indonesia juga mengalami kasus yang serupa dengan kasus BP, yaitu kasus semburan lumpur dan gas yang berada pada wilayah operasional PT Lapindo Brantas Inc., sehingga kasus tersebut lebih dikenal dengan sebutan kasus "Lumpur Lapindo". Berdasarkan hasil pemeriksaan Badan Pemeriksa Keuangan (2007), pada tanggal 29 Mei 2006 telah terjadi semburan lumpur panas di areal dekat lokasi eksplorasi Sumur Banjarpanji-1 di Desa Renokenongo, Kecamatan Porong, Kabupaten Sidoarjo, Propinsi Jawa Timur yang merupakan salah satu sumur di Blok Brantas milik Lapindo Brantas Inc. Akibat dari insiden ini, berdasarkan laporan ringkasan eksekutif yang dikemukakan Komisi Nasional Hak Asasi Manusia (2011) mengakibatkan sekurang-kurangnya 12 desa dan kelurahan atau lebih pada wilayah peta terdampak menjadi tenggelam, dan 30 pabrik terpaksa menghentikan produksi dan memberhentikan ribuan tenaga kerja dengan total jumlah 1.873 orang.

Kasus di Teluk Meksiko mengharuskan BP untuk mencapai kesepakatan sebesar US\$ 18,7 miliar untuk menyelesaikan proses litigasi dengan pemerintah Amerika Serikat karena terbukti melakukan tindakan grossly negligence dalam operasionalnya (Hays,2015). Konsekuensi lainnya juga harus diterima oleh BP, yaitu dengan adanya penurunan drastis nilai saham biasa BP pada tahun 2010 di London Stock Exchange menjadi hanya 296 pence/share (BP Annual Report,2010:134) dan juga dikeluarkannya kebijakan untuk pemberhentian aktivitas pengeboran (moratorium on drilling) bagi seluruh rig yang ada di kawasan deepwater Teluk Meksiko selama 6 bulan lamanya, terhitung sejak tanggal 30 Mei 2010 (Bertrand,2012).

Pelaksanaan tanggung jawab sosial dan lingkungan diatur dalam tata kelolxa perusahaan.Jika tanggung jawab sosial dan lingkungan tidak terlaksana dengan baik, hal yang menjadi perhatian utama adalah bagaimana tata kelola dari suatu perusahaan. Dan apabila tata kelola tidak berjalan dengan baik, kemungkinan perusahaan untuk 
melanggar hukum dan etika akan semakin besar, karena tata kelola sendiri berbicara mengenai bagaimana pengelolaan korporasi yang patuh pada hukum, beretika, serta bertanggung jawab kepada stakeholder. Pelanggaran hukum yang dilakukan oleh perusahaan akan menyebabkan perusahaan untuk berhadapan atau bahkan terlibat langsung dalam kejahatan korporasi.

Kejahatan korporasi memiliki berbagai bentuk di dunia modern saat ini.Salah satu kejahatan korporasi dengan dampak negatif yang begitu dahsyat adalah kasus tragedi Bhopal di India. Pada dini hari 3 Desember 1984, sekitar 40 ton gas methyl isocyanate tanpa sengaja bocor dari sebuah pabrik pestisida yang dimiliki oleh perusahaan multinasional Amerika Serikat Union Carbide Corp dan terbawa angin ke daerah kumuh yang berada di sekitar pabrik. Pemerintah mencatat 5295 kematian, namun aktivis memperkirakan 25 ribu kematian akibat penyakit sejak kebocoran terjadi (Agestu,2014). Selain tragedi Bhopal tersebut, berbagai kejahatan korporasi lainnya dilakukan oleh berbagai perusahaan yang memproduksi dan memasok kendaraan bermotor, dengan hukuman besar untuk pelanggaran keamanan, termasuk denda \$900 juta (dan ditangguhkan penuntutan pidana) untuk General Motors, denda sipil rekor \$200 juta untuk pembuat airbag Jepang Takata, hukuman dari \$ 105.000.000 dan \$ 70 juta untuk Fiat Chrysler, dan $\$ 70$ juta untuk Honda.

Lalu kemudian, bentuk kejahatan korporasi lainnya yang berkaitan dengan manipulasi keuangan, yaitu pada kasus yang dihadapi oleh lima bank (Citigroup, JPMorgan Chase, Barclays, Royal Bank of Scotland dan UBS) yang harus membayar total \$2,5 miliar untuk Departemen Kehakiman dan \$ 1.8 milyar untuk Federal Reserve sehubungan dengan tuduhan bahwa mereka bersekongkol untuk memanipulasi pasar valuta asing (Mattera,2015).
Oleh karena itu, tanggung jawab sosial dan lingkungan perusahaan bukan sekedar kegiatan pemenuhan tanggung jawab perusahaan kepada stakeholder semata.Tanggung jawab sosial dan lingkungan merupakan tindakan yang sangat diperlukan untuk mempertahankan keberlanjutan perusahaan dan menjaga perusahaan agar terhindar dari risiko terlibat dalam suatu kejahatan korporasi.

\section{Kerangka Teoritis}

\subsection{Tanggung Jawab Sosial dan Lingkungan}

Menurut Fontaine (2013), corporate social responsibility atau tanggung jawab sosial dan lingkungan adalah bentuk self regulation perusahaan yang diintegrasikan ke dalam model bisnis. Fungsi kebijakan CSR adalah sebagai mekanisme mengatur diri yang terintegrasi, dimana memantau bisnis dan memastikan kepatuhan aktif dengan semangat hukum, standar etika, dan norma-norma internasional. CSR adalah inklusi sengaja kepentingan publik dalam pengambilan keputusan perusahaan, dan menghormati triple bottom line: people, planet, profit.

Menurut Fontaine (2013) CSR atau tanggung jawab sosial dan lingkungan perusahaan adalah mengenai bagaimana bisnis mengarahkan nilainilai mereka dan perilaku mereka dengan ekspektasi dan kebutuhan dari para pemangku kepentingan - tidak hanya pelanggan dan investor, tetapi juga karyawan, pemasok, komunitas, regulator, kelompok kepentingan khusus, dan masyarakat secara keseluruhan. CSR mendeskripsikan komitmen perusahaan untuk menjadi akuntabel kepada para pemangku kepentingan.CSR meminta bisnis untuk mengelola dampak ekonomi, sosial, dan lingkungan dari operasional mereka untuk memaksimalkan manfaat dan meminimalkan kerugian.Menurut McWilliams dan Siegel (2001) dalam 
Fontaine (2013), corporate social responsibility terdiri dari tindakan yang muncul untuk lebih memajukan kebaikan sosial di luar kepentingan perusahaan dan yang diwajibkan oleh hukum. Sedangkan definisi lainnya yang tidak jauh berbeda, dikemukakan oleh pernyataan Carol (1979) dalam Fontaine (2013), bahwa tanggung jawab sosial dari bisnis meliputi ekspektasi ekonomi, hukum, etika, dan diskresioner yang dimiliki masyarakat terhadap organisasi pada suatu titik waktu tertentu.

\subsection{Definisi Korporasi Kejahatan Korporasi}

dan

Pengertian korporasi sebagai badan hukum tertuang dalam Black's Law Dictionary dalam Ali (2008) sebagai berikut :

"An entity (usually a business) having authority under Law to act as a single person distinct from the shareholders who own it and having rights to issues stock and exist indefinitely, a group or succession of persons established in accordance with legal rules into or jurisdic that has legal personality distinct from the natural persons who make it up, exist indefinitely a part from them, and has the legal powers that it constitution gives it."

Hutauruk

mengemukakan bahwa badan yang diciptakan itu terdiri dari corpus, yaitu struktur fisiknya dan kedalamnya hukum memasukkan unsur animus yang membuat badan itu mempunyai kepribadian.Oleh karena badan hukum itu merupakan ciptaan hukum maka kecuali penciptaannya, kematiannya pun juga ditentukan oleh hukum.Korporasi sering pula disebut sebagai legal entities atau rechtpersoon dengan maksud untuk menjelaskan bahwa badan tersebut memiliki identitas hukum yang memiliki kekayaan serta hak dan kewajiban yang terpisah dari anggota-anggotanya.
Clinard dan Yeager (1980:16) dan Weda (1993:3) dalam Ali (2008) memberikan pengertian bahwa kejahatan korporasi dapat diartikan sebagai setiap tindakan yang dilakukan oleh korporasi yang bisa diberi hukuman oleh negara, entah di bawah hukum administrasi negara, hukum perdata, maupun hukum pidana. Sedangkan menurut Kramer (1984:31), kejahatan korporasi adalah kejahatan yang dilakukan oleh organisasi korporat.Hal ini adalah hasil dari kebijakan yang diambil oleh para petinggi perusahaan.Dan perusahaan membuat keputusan tersebut untuk memperoleh keuntungan untuk perusahaan.

Salah satu definisi yang mudah dipahami adalah definisi dari Brathwaite (1984) dalam Simpson (2002) bahwa kejahatan korporasi adalah perilaku korporasi, atau karyawan yang bertindak atas nama sebuah perusahaan, yang ditentukan dan dihukum oleh hukum. Tiga ide kunci tentang kejahatan korporasi dapat diketahui melalui definisi ini, bahwa (1) ilegalitas dari sebuah korporasi beserta agen-agennya berbeda dengan perilaku kriminal kelas sosial bawah terutama pada prosedur administrasi yang digunakan ketika menghadapi pelaku pelanggaran, sehingga kejahatan korporasi tidak hanya melibatkan pelanggaran terhadap hukum pidana, tetapi juga termasuk pelanggaran terhadap hukum sipil dan perdata.

Kemudian, poin ke (2) yaitu bahwa korporasi sebagai "legal persons" dan para perwakilannya juga diakui sebagai aktor yang melakukan tindakan ilegal. Faktor yang menentukan apakah masing-masing perwakilan terpilih sebagai target penjatuhan sanksi atau tidak, akan tergantung pada jenis tindakan yang dilakukan, aturan dan kualitas bukti, preferensi jaksa, dan sejarah dari perusahaan / korporasi tersebut. Menurut Coleman (1989) dalam Simpson(2002), pada akhirnya, definisi dari Braithwaite (1984) menentukan (3) motivasi yang mendasari untuk menyinggung 
perusahaan: secara keseluruhan, ilegalitas tidak dikejar untuk manfaat dan kepentingan individu melainkan untuk tujuan organisasi. Dengan demikian, dalam rangka mempertahankan keuntungan, mengelola pasar yang tidak menentu, biaya perusahaan lebih rendah, atau menempatkan saingan keluar dari bisnis, perusahaan dapat mencemari lingkungan, terlibat di penipuan keuangan dan manipulasi, memperbaiki harga, menciptakan dan memelihara kondisi kerja berbahaya, sengaja menghasilkan produk yang tidak aman, dan sebagainya. Keputusan manajer untuk melakukan tindakan tersebut (atau untuk memerintahkan atau diam-diam mendukung orang lainmelakukannya) dapat didukung oleh norma-norma operasional dan subkultur organisasi.

\subsection{Karakteristik Kejahatan Korporasi dan Sistem Pertanggungjawaban Korporasi}

Mengenai karakteristik dari white collar crimes pada umumnya dan karakteristik kejahatan korporasi pada khususnya adalah sebagai berikut : (1) low visibility , (2) complexity, (3) diffusion of responsibility , (4) the diffusion of victimization, (5) difficult to detect and prosecute, (6) lenient sanctions , (7) ambiguous laws , (8) ambiguous criminalstatus (Croall, 1993 : 12-6, dan Muladi, 1996:5) dalam Setiyono(2004:43).

Dalam penelitian ini, peneliti menggunakan sistem pertanggungjawaban yang ketiga untuk korporasi sebagai subjek pidana.Hal-hal yang bisa dipakai sebagai dasar pembenar dan alasan bahwa korporasi sebagai pembuat dan sekaligus yang bertanggungjawab adalah karena dalam berbagai delik-delik ekonomi dan fiskal keuntungan yang diperoleh korporasi atau kerugian yang diderita masyarakat dapat demikian besarnya, sehingga tidak akan mungkin seimbang bilamana pidana hanya dijatuhkan kepada pengurus korporasi saja.

Menurut Muladi (1989) dalam Ali (2008) sistem pertanggungjawaban yang ketiga ini telah terjadi pergeseran pandangan, bahwa korporasi dapat dipertanggungjawabkan sebagai pembuat, disamping manusia alamiah (natuurlijk persoon). Jadi, penolakan pemidanaan korporasi berdasarkan doktrin universitas delinguere non potest sudah mengalami perubahan dengan menerima konsep pelaku fungsional (functioneel daaderschap).

\subsection{Teori pertanggungjawaban Korporasi}

Berdasarkan pernyataan dari (Reid,1995) dalam Suhartati(2015), Strict liability diartikan sebagai suatu pertanggungjawaban pidana dengan tidak mensyaratkan adanya kesalahan pada diri pelaku terhadap satu atau lebih actus reus. Strict liability ini merupakan pertanggungjawaban tanpa kesalahan (liability without fault).Seperti yang diungkapkan oleh Hanafi (1997) dalam Ali (2008), dapat ditegaskan bahwa dalam perbuatan pidana yang bersifat strict liability hanya dibutuhkan dugaan atau pengetahuan dari pelaku (terdakwa), sudah cukup menuntut pertanggungjawaban pidana daripadanya. Jadi, tidak dipersoalkan adanya mens rea karena unsur pokok strict liability adalah actus reus (perbuatan), sehingga yang harus dibuktikan adalah actus reus (perbuatan) bukan mens rea (kesalahan).

Doktrin lainnya yang berbeda dengan doktrin strict liability yaitu doktrin vicarious liability.Doktrin vicarious liability sebagaimana dijelaskan oleh Simester dan Brookbanks (2002) dalam Suhartati (2015) adalah :"vicarious liability involves the attribution to one individual or corporation of criminal liability for the acts of another. The defendant bears liability on behalf of another."

Sementara itu menurut Slapper dan Tombs (1999) dalam Suhartati 
(2015) menyatakan bahwa "Vicarious liability is a form of strict liability arising from the employer-employee relationship without reference to any fault of employer. A corporation is responsible to exactly the same extent as an individual employer for the acts of its employees." Berdasarkan pendapat yang dikemukakan Slapper dan Tombs (1999) dalam Suhartati (2015) tersebut terdapat dua syarat penting yang harus dipenuhi jika menerapkan perbuatan pidana dengan vicarious liability yaitu : (1) harus terdapat suatu hubungan, yaitu hubungan pekerjaan antara atasan dengan bawahan, lalu syarat ke (2) yaitu perbuatan pidana yang dilakukan oleh pekerja / bawahan tersebut harus berkaitan atau masuk dalam ruang lingkup pekerjaannya.

\subsection{Definisi Stakeholder dan Teori Stakeholder}

Menurut Lawrence dan Weber (2008), stakeholder merujuk kepada orang atau sekumpulan orang yang mempengaruhi, atau dipengaruhi oleh keputusan, kebijakan, dan operasional dari suatu organisasi.Terdapat dua kategori stakeholder, yaitu Market Stakeholderyang merupakan orangorang yang terlibat dalam transaksi ekonomi dengan perusahaan karena melakukan tujuan utamanya menyediakan masyarakat dengan barang dan jasa. Contoh yang termasuk market stakeholder yaitu karyawan, pemegang saham, kreditor, pemasok, pembeli, distributor.

Kemudian, juga terdapat Non Market Stakeholderyaitu orang dan kelompok yang meskipun mereka tidak terlibat dalam pertukaran ekonomi langsung dengan perusahaan- namun tetap terpengaruh oleh atau dapat mempengaruhi tindakan perusahaan itu. Contohnya yang termasuk non market stakeholder yaitu masyarakat umum, media, grup aktivis, pemerintah, business support groups, dan komunitas (Lawrence dan Weber,2008).Stakeholder Theory atau
Teori Pemangku Kepentingan yang dikemukakan oleh Lawrence dan Weber (2008) adalah suatu pandangan yang mengungkapkan bahwa korporasi menyajikan tujuan publik yang lebih luas: untuk menciptakan value bagi masyarakat.

\subsection{Tata Kelola Perusahaan dan Etika Bisnis}

Berdasarkan Cadbury Report (1992) yang dimaksud dengan corporate governance adalah sistem yang mengarahkan dan mengendalikan perusahaan.Corporate governance atau tata kelola perusahaan melibatkan sekumpulan hubungan antara pihak manajemen perusahaan, direksi, pemegang saham, dan pihak lain yang mempunyai kepentingan dengan perusahaan.Corporate governance juga mensyaratkan adanya struktur perangkat untuk mencapai tujuan dan pengawasan atas kinerja (OECD,2004).

Corporate governance (tata kelola perusahaan) dapat dianggap sebagai lingkungan kepercayaan, etika, nilai moral, dan keyakinan, sebagai upaya sinergis dari semua konstituen masyarakat. Sehingga, perusahaan atau korporasi sebagai salah satu bagian dari kehidupan di masyarakat memiliki kewajiban untuk memiliki dan mengimplementasikan tata kelola perusahaan dengan sebaik mungkin (Aras dan Crowther,2008).Terdapat lima prinsip Good Corporate Governance yang dapat dijadikan pedoman, yaitu Transparency, Accountability, Responsibility, Independency, dan Fairness (Wibisono, 2007).

Pelaksanaan corporate governance (tata kelola perusahaan) sangatlah berhubungan dengan etika bisnis. Yang dimaksud dengan business ethics atau etika bisnis adalah suatu aplikasi dari konsep etika secara umum kepada perilaku bisnis.Etika bisnis bukan merupakan rangkaian khusus dari 
konsep etika yang berbeda dengan etika secara umum dan dapat diaplikasikan hanya untuk bisnis saja (Lawrence dan Weber,2008). Etika bisnis terdiri dari seperangkat prinsip dan nilai-nilai (Jones et al.,2005) moral yang mengatur perilaku organisasi sehubungan dengan apa yang benar dan apa yang salah (Badiou, 2001; Seglin, 2003) dalam (Velentzas dan Broni,2010).

\section{Metodologi Penelitian}

Penelitian ini menggunakan pendekatan kualitatif dan secara spesifik diarahkan pada penggunaan metode analisis isi (Content Analysis).Menurut (Kondracki \& Wellman, 2002) analisis isi (content analysis) digunakan untuk mengembangkan kesimpulan yang obyektif tentang topik yang menarik di setiap jenis komunikasi.

Dalam penelitian ini, data didapatkan melalui satu sumber, yaitu data sekunder. Peneliti melaksanakan penelitian berdasarkan sumber data yang diperoleh dari laman Internet, khususnya dari website resmi perusahaan dan dari berbagai situs berita yang terpercaya dan kredibel. Data-data sekunder lainnya diperoleh peneliti dari sumber lainnya seperti berita elektronik, jurnal, laporan, laporan keberlanjutan, dan dari buku teks.Seluruh data sekunder yang didapatkan dan diunduh dari peneliti berasal dari sumber yang kredibel dan hanya menyajikan fakta.

Untuk memastikan reliabilitas dan validitas data, peneliti melakukan triangulasi.Triangulasi merupakan teknik pemeriksaan keabsahan data melalui sumber lain. Peneliti melakukan triangulasi dalam dua cara, yaitu: (1) menggunakan bahan referensi, (2) menggunakan metode triangulasi sumber dalam memeriksa keabsahan data. Lalu kemudian, peneliti melakukan triangulasi sumber untuk data-data faktual seperti berita elektronik yang dimuat di internet. Triangulasi sumber tersebut dilakukan dengan cara mencocokkan data yang isinya sama, namun berasal dari berbagai sumber yang berbeda-beda, yang telah teruji kredibilitasnya.

Untuk memudahkan peneliti dalam melakukan analisis, peneliti mengembangkan tiga mini research questions :

1.Bagaimana implementasi
aktivitas terkait tanggung
jawab sosial dan lingkungan
dari PT Lapindo Brantas Inc.
kepada para stakeholder?
2.Bagaimana potensi munculnya
dugaan kejahatan korporasi
yang dilakukan perusahaan
pertambangan khususnya PT
Lapindo Brantas Inc.?
3. Bagaimana implikasi tanggung
jawab sosial dan lingkungan
terkait potensi dugaan
kejahatan korporasi pada PT
Lapindo Brantas Inc.?

\section{Analisis Data dan Pembahasan}

Sebagai bagian dari masyarakat setempat, di mana perusahaan beroperasi, Lapindo menjalankan kegiatan operasinya dengan komitmen penuh dan konsisten dalam mencegah terjadinya kecelakaan terhadap manusia, kerusakan terhadap harta benda serta lingkungan hidup. Kegiatan pengelolaan dampak lingkungan fokus pada pengelolaan limbah cair dan padat, sedangkan pada program pengembangan masyarakat terdapat empat pilar utama: pemberdayaan ekonomi, perbaikan infrastruktur, pendidikan dan kesehatan.

Melalui laporan hasil audit yang dikeluarkan oleh Badan Pemeriksa Keuangan (2007) telah diketahui bahwa pada tanggal 29 Mei 2006 telah terjadi semburan lumpur panas di areal dekat lokasi eksplorasi sumur Banjarpanji-1 di Desa Renokenongo, Kecamatan Porong, Kabupaten Sidoarjo, Propinsi Jawa Timur yang merupakan salah satu sumur di Blok Brantas milik Lapindo. 
Erupsi (semburan) lumpur panas ini terjadi tepatnya pada pukul 4.30 WIB, sekitar 200 meter arah barat daya dari sumur BJP-1. Erupsi (semburan) lumpur panas ini kemudian dikenal dengan Lumpur Sidoarjo.Semburan tersebut terjadi ketika pemboran sumur BJP-1 belum selesai dan telah memasuki hari ke 80 dari rencana 37 hari (Badan Pemeriksa Keuangan,2007).

Seiring dengan berjalannya waktu, semburan lumpur lapindo tidak henti-hentinya mengalir, mengakibatkan timbul bencana Lumpur Lapindo. Semburan lumpur lapindo ini mengakibatkan sekurang-kurangnya 12 desa dan kelurahan atau lebih dalam wilayah peta terdampak menjadi tenggelam dalam luas lebih dari 600 hektar, menyebabkan berpindahnya sekitar 40 ribu sampai dengan 60 ribu orang atau setidak-tidaknya dalam jumlah puluhan ribu orang dari tempat tinggal mereka yang sah, yang mayoritasnya adalah penduduk sipil. Kemudian, 1.605 ekor hewan ternak seperti unggas, 30 kambing, 2 sapi, dan 7 ekor kijang telah musnah, 30 pabrik terpaksa menghentikan produksi dan memberhentikan ribuan tenaga kerja dengan total jumlah 1.873 orang. Infrastruktur menjadi rusak, yang ditunjukkan dengan tak berfungsinya empat kantor pemerintahan, sekolah, Markas Koramil Porong serta rusaknya jaringan listrik dan telepon akibat terjangan lumpur. Rumah atau tempat tinggal yang rusak diterjang lumpur sebanyak 1683 unit (Komisi Nasional Hak Asasi Manusia, 2011).

Sebagai pembanding dengan kasus lumpur Lapindo, terdapat juga kasus serupa yang dialami oleh perusahaan asal Inggris yang bergerak dalam bidang migas, yakni British Petroleum p.l.c atau yang selanjutnya akan peneliti singkat menjadi BP. Kasus yang dialami BP adalah kasus tumpahan minyak mentah dan ledakan rig Deepwater Horizon yang terjadi pada 20 April 2010 silam, juga mengakibatkan dampak negatif yang tidak kalah besar dan luas dengan dampak negatif daripada yang ditimbulkan pada kasus lumpur Lapindo. Dampak negatif dari kasus Teluk Meksiko antara lain; Pemerintah AS menutup 37\% wilayah perairan federal dari aktivitas penangkapan ikan, Industri perikanan komersial Teluk Meksiko diperkirakan telah mengalami kerugian \$ 247 miliar akibat dari penutupan wilayah pemancingan hasil laut, setelah terjadinya tumpahan minyak, dan Kematian mamalia laut sudah setingkat kematian 5000 individu, hampir 1 juta burung laut pesisir dan lepas pantai diperkirakan telah mati sebagai akibat dari tumpahan minyak (NRDC,2015).

Upaya dalam bentuk berbagai penelitian dilakukan para ilmuwan dan akademisi guna mencari penyebab dari semburan lumpur Lapindo ini, sekaligus sebagai upaya untuk menghentikan semburan lumpur yang terus mengalir.Hal yang menarik adalah, dari berbagai penelitian yang dilakukan oleh para ilmuwan dan akademisi, tidak tercapai suatu kesepakatan bersama mengenai penyebab lumpur Lapindo. Terdapat dua jenis kesimpulan yang dihasilkan oleh para ilmuwan, bahwasanya lumpur lapindo disebabkan oleh kemungkinan kesalahan pengeboran yang dilakukan perusahaan, dan kesimpulan lainnya mengatakan bahwa lumpur Lapindo disebabkan oleh adanya pengaruh dari Gempa Yogyakarta, sehingga kasus ini dapat dikatakan sebagai bencana alam.

Para ahli geologi Lapindo mengemukakan dalam (LUSI Report, 2014:2) bahwa semburan lumpur memiliki kaitan dengan kegiatan 62eismic akibat gempa yang terjadi dua hari sebelumnya, yang juga berkaitan dengan aktifnya kembali Gunung Semeru yang terletak $300 \mathrm{~km}$ dari episentrum gempa bumi Yogyakarta. Hal senada juga diungkapkan oleh pakar geodinamika dari Universitas Bonn, Jerman, yakni Stephen Miller, yang mengungkapkan bahwa semburan lumpur Lapindo adalah murni bencana alam yang disebabkan gempa 
berkekuatan 6,3 skala richter yang terjadi dua hari sebelumnya di Yogyakarta (Ferri, 2014).

Kesimpulan yang lain menyatakan bahwasanya kejadian lumpur Lapindo tersebut disinyalir merupakan akibat dari kelalaian Lapindo saat melakukan pengeboran. Berdasarkan data yang peneliti peroleh dari ringkasan laporan Badan Pemeriksa Keuangan (2007), saat pengeboran sumur BJP-1 dengan kedalaman 9.297 kaki, oleh PT LBI / PT MCN casing baru dipasang hanya sampai kedalaman 3580 kaki, sehingga terdapat bagian sumur yang belum dipasang casing atau dibiarkan tetap terbuka (Open hole) sedalam 5.717 kaki. Open hole yang panjang tersebut mempunyai pengaruh terhadap kecepatan dan ketepatan penyelesaian well problem seperti well kick dan well loss.

Kesimpulan yang dikemukakan oleh Badan Pemeriksa Keuangan tersebut juga didukung dengan hasil penelitian ilmuwan internasional. Hasil penelitian yang diungkapkan oleh Richard Davies dalam jurnalnya yaitu "The East Java Mud Volcano (2006 to present): An earthquake or drilling trigger?" menyimpulkan bahwa penyebab dari kasus lumpur lapindo dikarenakan karena kesalahan saat pengeboran. Menurut Davies et al. (2008), kejadian kunci yang merupakan penyebab dari semburan lumpur sidoarjo adalah ketika penghapusan bor dan pipa bor pada tanggal $27-28$ Mei yang menyebabkan "influx of formation" bagi cairan dan gas ke dalam sumur bor saat operasi ini dilakukan. Dokumen dari Tritech Petroleum Consultants Limited yang ditujukan kepada Medco Group, juga turut mendukung kesimpulan bahwa penyebab lumpur Lapindo dikarenakan oleh kesalahan pengeboran (TriTech Petroleum Preliminary Report, 2006).

Setelah perdebatan panjang mengenai penyebab lumpur Lapindo terus bergulir, pada akhirnya Mahkamah Agung memutuskan bahwa kasus lumpur Lapindo merupakan suatu bencana alam.Sehingga, dapat dikatakan bahwa terjadinya kasus lumpur Lapindo tersebut apabila dilihat sebagai bencana alam, merupakan kasus yang terjadi karena ketidaksengajaan yang lebih kuat, yang disebabkan oleh faktor gejolak alam.

Kasus lumpur Lapindo dapat diduga berpotensi sebagai kejahatan korporasi karena beberapa hal, diantaranya yaitu terdapat beberapa karakteristik dugaan kejahatan korporasi seperti the diffusion of victimization, difficult to detect and prosecute, complexity, lenient sanctions, dan diffusion of responsibility. Namun, secara de jure, kembali lagi pada keputusan dari Mahkamah Agung bahwa kasus lumpur Lapindo telah ditetapkan sebagai bencana alam.

Fakta mengenai penyebaran korban yang sangat luas ditunjukkan melalui tenggelamnya desa-desa dan kelurahan di wilayah Kecamatan Porong, Jabon, dan Tanggulangin, sekurang-kurangnya terdapat 12 desa dan kelurahan atau lebih sebagai wilayah terdampak, dalam luas lebih dari 600 hektar, menyebabkan berpindahnya sekitar 40 ribu sampai dengan 60 ribu orang atau setidaktidaknya dalam jumlah puluhan ribu orang dari tempat tinggal mereka yang sah, yang mayoritasnya adalah penduduk sipil (Komisi Nasional Hak Asasi Manusia,2011).

Kasus lumpur lapindo ini berpotensi untuk diduga sebagai kejahatan korporasi karena terdapat hambatan dalam pendeteksian pelaku dan penuntutan (difficult to detect and prosecute). Setelah dilakukan serangkaian pemeriksaan, 12 orang sudah ditetapkan sebagai tersangka, salah satunya adalah General Manager Lapindo Brantas Imam Agustino (detikNews,2007). Namun, rangkaian kegiatan penyidikan yang dilakukan oleh Polda Jatim ini pada akhirnya dihentikan dengan keluarnya SP3 pada tanggal 7 Agustus 2009. Alasan Polda 
Jatim karena dalam kasus ini tidak ada bukti yang kuat yang bisa membuktikan korelasi antara pengeboran sumur Banjar Panji 1 dengan luapan lumpur yang berjarak 150 meter (Tejo,2009).

Menurut peneliti, berkenaan dengan hal kompleksitas, kasus lumpur lapindo ini merupakan potensi dugaan kejahatan yang sangat kompleks karena berkaitan dengan hal yang ilmiah dan teknologi canggih. Hal itu disebabkan karena potensi dugaan kejahatan tersebut berbicara mengenai apakah Lapindo dapat diduga telah melakukan kejahatan korporasi jenis kejahatan lingkungan dikarenakan terdapat tindakan terkait prosedur pengeboran yang diduga telah dilanggar oleh perusahaan, dan berbicara mengenai apakah standar keamanan untuk proses pengeboran sumber minyak dan gas telah dipatuhi, analisis risiko, serta berbicara mengenai dugaan kepatuhan perusahaan terhadap peraturan perundangan telah dipenuhi atau belum.

Dugaan kejahatan yang sangat kompleks ini, diduga dilakukan oleh pihak-pihak yang memiliki jabatan tinggi di perusahaan dan ahli yang terdidik, yang berada di dalam lingkup suatu perusahaan (korporasi), serta dilakukan secara terorganisir dan melibatkan banyak pihak.

Karakteristik selanjutnya yang ada pada kasus ini dan berpotensi memunculkan dugaan kejahatan korporasi yaitu diffusion of responsibility.Penyebaran tanggung jawab dapat dilihat bahwasanya sebelum ditetapkan sebagai bencana alam, Polres Sidoarjo telah melakukan investigasi hingga akhirnya menetapkan 12 tersangka, termasuk didalamnya adalah general managerLapindo Brantas, Imam Agustino. Apabila dilihat melalui dugaan penyebabnya, yaitu dugaan adanya kesalahan pengeboran, maka diantara keduabelas tersangka tersebut, belum dapat dipastikan siapa yang benar-benar berperan sebagai penanggung jawab indikasi adanya dugaan kelalaian saat pengeboran di sumur BanjarPanji. Belum dapat ditelusuri dan ditentukan, apakah kejadian semburan lumpur lapindo tersebut merupakan kesalahan pengeboran yang merupakan tanggung jawab manajemen \& manajer selaku decision maker, atau mungkin tanggung jawab harus dilimpahkan kepada drilling supervisor selaku pihak yang seharusnya menjalankan fungsi pemeriksaan peralatan dan pengawasan kegiatan pengeboran, atau bahkan tenaga kerja pengeboran yang harus mengemban tanggung jawab karena dianggap lalai dan kurang berkompeten seperti halnya yang tertuang dalam laporan hasil audit Badan Pemeriksa Keuangan.

Karakteristik selanjutnya yang ada pada kasus ini dan berpotensi memunculkan dugaan kejahatan korporasi yaitu diffusion of responsibility.Penyebaran tanggung jawab dapat dilihat bahwasanya sebelum ditetapkan sebagai bencana alam, Polres Sidoarjo telah melakukan investigasi hingga akhirnya menetapkan 12 tersangka, termasuk didalamnya adalah general manager Lapindo Brantas, Imam Agustino. Apabila dilihat melalui dugaan penyebabnya, yaitu dugaan adanya kesalahan pengeboran, maka diantara keduabelas tersangka tersebut, belum dapat dipastikan siapa yang benar-benar berperan sebagai penanggung jawab indikasi adanya dugaan kelalaian saat pengeboran di sumur BanjarPanji. Belum dapat ditelusuri dan ditentukan, apakah kejadian semburan lumpur lapindo tersebut merupakan kesalahan pengeboran yang merupakan tanggung jawab manajemen \& manajer selaku decision maker, atau mungkin tanggung 
jawab harus dilimpahkan kepada drilling supervisor selaku pihak yang seharusnya menjalankan fungsi pemeriksaan peralatan dan pengawasan kegiatan pengeboran, atau bahkan tenaga kerja pengeboran yang harus mengemban tanggung jawab karena dianggap lalai dan kurang berkompeten seperti halnya yang tertuang dalam laporan hasil audit Badan Pemeriksa Keuangan.

Karakteristik mengenai dugaan adanya kejahatan korporasi yang dapat ditemukan pada kasus lumpur Lapindo ini secara tidak langsung memunculkan 65eismi kesengajaan yang dilakukan oleh korporasi, sehingga kasus ini juga berpotensi besar untuk diduga sebagai kejahatan korporasi.Pada penelitian ini, kasus BP di Teluk Meksiko digunakan sebagai pembanding (benchmark) dengan kasus yang dihadapi oleh Lapindo. Pada awal kasus di Teluk Meksiko sedang ramai diberitakan, $\mathrm{CEO}$ BP pada saat itu, Tony Hayward, bersikeras menyatakan bahwa kejadian di Teluk Meksiko bukanlah kejadian yang disebabkan oleh BP (Bergin,2010).

Penyangkalan BP tersebut pada akhirnya dipatahkan oleh bukti-bukti yang sudah ada, sehingga berdasarkan keputusan pengadilan federal yang diputuskan oleh hakim pengadilan distrik federal AS, Carl Barbier, menyatakan bahwa BP telah melakukan tindakan yang sangat lalai dan disengaja terkait dengan pengabaian hasil tes yang menunjukkan bahwa sumur Macondo di Teluk Meksiko tidak stabil dan sangat beresiko tinggi jika dilakukan pengeboran minyak. Pengacara untuk pemerintah AS dan korban tumpahan minyak mengatakan kepada hakim Barbier di pengadilan selama fase pertama litigasi, bahwa BP mengalami over-budget sebesar $\$ 60$ miliar dan tertinggal selama 54 hari dari jadwal semula. Hal tersebut mendorong BP untuk mengambil jalan pintas guna menghemat biaya dengan cara mengabaikan tes keselamatan yang menunjukkan sumur Macondo tidak stabil (Fisk, Calkins, dan Feeley,2014).

Sehingga, dapat diketahui bahwa kasus di Teluk Meksiko yang disebabkan oleh BP melibatkan 65eismi kesengajaan.Unsur kesengajaan tersebut dapat dilihat pada tindakan BP yang terbukti telah mengabaikan hasil tes yang menyatakan bahwa sumur Macondo tidak stabil dan sangat berisiko tinggi jika dilakukan pengeboran.Dengan demikian, peneliti dapat menyimpulkan bahwa BP telah melakukan suatu tindak kejahatan korporasi. Apabila melihat dari kasus $\mathrm{BP}$, tindakan lalai dan disengaja yang telah dilakukan oleh BP telah dikenakan pertanggungjawaban pidana oleh Pemerintah AS, dan kondisi serupa juga dapat dialami oleh Lapindo jika dugaan 65eismi kesengajaan dan kesalahan pengeboran terbukti lebih kuat pada kasus lumpur Lapindo.

Apabila peneliti meninjau dari sisi kesimpulan bahwa kasus lumpur Lapindo diduga disebabkan oleh kesalahan pengeboran, dan apabila telah terdapat bukti yang mendukung serta menunjukkan terdapat 65eismi kesengajaan telah dilakukan perusahaan, maka tidak menutup kemungkinan bahwa kasus lumpur Lapindo ini juga dapat dikenai pertanggungjawaban pidana.

Teori-teori Pertanggungjawaban Korporasi yang akan digunakan oleh peneliti dalam penelitian ini adalah teori Strict Liability dan teori Vicarious Liability. Menurut Reid (1995), strict liability ini merupakan pertanggungjawaban tanpa kesalahan (liability without fault). Apabila potensi munculnya dugaan kejahatan korporasi lebih cenderung ditemukan pada kasus lumpur Lapindo ini, peneliti mendukung penggunaan konsep strict liability sebagai bentuk pertanggungjawaban pidana yang harus diemban korporasi.

Konsep strict liability yang didasarkan pada asas res ipsa loquitur, sesuai dengan fakta yang sudah ada, yang telah menunjukkan bahwa kasus semburan lumpur lapindo telah 
menimbulkan kerugian yang sangat 66eismi, dapat dilihat dari puluhan ribu jiwa penduduk yang telah kehilangan tempat tinggal dan fungsi sosialnya di masyarakat, serta kerugian materiil dan 66eismic66al yang sangat besar dan tentunya sangat merugikan masyarakat di kecamatan Porong, merugikan Pemkab Sidoarjo, dan yang pastinya sangat merugikan Negara.

Selain menggunakan konsep strict liability, pertanggungjawaban pidana bagi Lapindo apabila didasarkan pada potensi dugaan kejahatan korporasi yang ada pada kasus tersebut, juga dapat menggunakan konsep vicarious liability. Berdasarkan pendapat yang dikemukakan Slapper dan Steve (1999) dalam Suhartati (2015) tersebut terdapat dua syarat penting yang harus dipenuhi jika menerapkan perbuatan pidana dengan vicarious liabilityyaitu : (1) harus terdapat suatu hubungan, yaitu hubungan pekerjaan antara atasan dengan bawahan, lalu syarat ke (2) yaitu perbuatan pidana yang dilakukan oleh pekerja atau bawahan tersebut harus berkaitan atau masuk dalam ruang lingkup pekerjaannya.

Menurut pengamatan peneliti, teori vicarious liability ini sebenarnya telah dilakukan oleh pihak Polda Jatim saat tahap awal penyidikan dengan penetapan 12 tersangka dalam kasus lumpur lapindo ini, dimana pihak-pihak yang ditetapkan sebagai tersangka juga mencakup berbagai tingkatan jabatan di dalam perusahaan maupun pada perusahaan rekanan Lapindo (detikNews,2006). Akan tetapi, dari kedua konsep ini, baik strict liability maupun vicarious liability tidak dapat diterapkan untuk meminta pertanggungjawaban pidana pada kasus lumpur Lapindo, karena kembali lagi kepada status pada kasus lumpur Lapindo yang telah ditetapkan sebagai bencana nasional. Jika didasarkan pada Undang-Undang Pengelolaan Lingkungan Hidup No.23 tahun 1997 Pasal 35, Lapindo dapat terbebas dari kewajiban membayar ganti rugi karena pencemaran dan atau perusakan lingkungan hidup apabila disebabkan oleh adanya bencana alam. Karena telah ditetapkan oleh Pemerintah sebagai bencana alam, Lapindo juga dapat terbebas dari pertanggungjawaban pidana.

Jika merujuk pada UndangUndang Perseroan Terbatas No. 40 tahun 2007, pada pasal 74 telah dinyatakan bahwa Perseroan yang menjalankan kegiatan usahanya di bidang dan/ atau berkaitan dengan sumber daya alam wajib melaksanakan tanggung jawab sosial dan lingkungan. Sehingga, dapat diartikan bahwa korporasi atau perusahaan membutuhkan tanggung jawab sosial lingkungan sebagai persetujuan eksplisit maupun implisit dari pemerintah tuan rumah, komunitas, dan para pemangku kepentingan (Danko et al,2008). Oleh karena itu, mekanisme tanggung jawab sosial lingkungan yang dimiliki Lapindo merupakan suatu kewajiban yang harus ditaati oleh Lapindo.Hal tersebut sekaligus menegaskan bahwa Lapindo sebagai bagian dari masyarakat juga diharuskan untuk memiliki dan mengimplementasikan tanggung jawab sosial lingkungan agar mendapat persetujuan para pemangku kepentingan untuk menjalankan aktivitas bisnisnya.

Tanggung jawab sosial lingkungan Lapindo diwujudkan dalam pengelolaan dampak lingkungan dan program pengembangan masyarakat.Menurut peneliti, program pengelolaan dampak lingkungan sendiri bertujuan untuk mengelola limbah dan meminimalkan risiko perusakan lingkungan sebagai akibat dari aktivitas Lapindo.Kemudian, program pengembangan masyarakat sendiri bertujuan meminimalkan dampak negatif Lapindo pada keadaan sosial masyarakat sekaligus memberdayakan masyarakat di sekitar operasional Lapindo.

Jika merujuk pada pendapat (Fontaine, 2013) yang telah peneliti ungkapkan sebelumnya, implementasi tanggung jawab sosial lingkungan dari Lapindo ini juga dapat dikatakan sebagai 
cara Lapindo untuk mengarahkan tindakan mereka agar senantiasa sesuai dengan harapan para pemangku kepentingan, yakni bahwa Lapindo diharapkan untuk selalu menjaga lingkungan, meminimalkan dampak negatif, dan memaksimalkan dampak positif dari keberadaan mereka untuk masyarakat.

Kasus lumpur Lapindo juga sangat berdampak besar bagi reputasi Lapindo. Menurut peneliti, jika didasarkan pada pendapat dari (Fontaine, 2013) pelaksanaan tanggung jawab sosial lingkungan yang dilakukan setelah munculnya kasus ini bahwasanya digunakan untuk mengelola dan memperbaiki risiko reputasi perusahaan, dan mengelola risiko lingkungan yang akan dihadapi oleh Lapindo.

Tanggung jawab sosial dan lingkungan yang diimplementasikan Lapindo setelah terjadinya kasus Lumpur Lapindo beberapa diantaranya yaitu, peluncuran bantuan paket keuangan jangka panjang untuk pembelian tanah dan bangunan dari masyarakat yang terkena dampak bencana, penyediaan pemukiman baru di Kahuripan Nirvana Village oleh Lapindo Brantas(Lapindo LUSI Report, 2014), dan upaya penghentian lumpur melalui metode penghentian snubbing unit, side tracking, relief well, high density chained ball (Badan Pemeriksa Keuangan, 2007).

$$
\text { Apabila diperbandingkan }
$$

dengan kasus yang dialami oleh BP di Teluk Meksiko, kondisi BP juga tidak jauh berbeda dengan kondisi Lapindo.Dampak negatif yang 67eismi dan meluas sebagai akibat dari tindakan BP di Teluk Meksiko memunculkan berbagai tuntutan dari masyarakat dan Pemerintah Amerika Serikat.Di tahun 2010, perusahaan harus mengeluarkan biaya sebesar $\$ 40$ miliar lebih sebagai cleanup costspada kasus di Teluk Meksiko, BP Plc telah mencapai kesepakatan untuk membayar 67eismic sebesar \$ 18,7 miliar karena telah terbukti bersalah bahwa BP melakukan operasinya di Teluk Meksiko secara grossly negligent, dan $\$ 4,9$ miliar untuk menyelesaikan klaim ekonomi oleh lima 67eismi yang harus dibayar lebih dari 18 tahun(Hays,2015).

Apabila dikaitkan dengan stakeholder theory yang dikemukakan oleh Lawrence dan Weber (2008), dalam pandangan ini, korporasi memiliki banyak kewajiban, dan salah satu kewajiban tersebut adalah senantiasa memperhitungkan kepentingan pemangku kepentingan dalam rangka memenuhi kebutuhan para pemangku kepentingan.Masyarakat Porong dan sekitarnya selaku stakeholder yang menjadi korban dalam kasus lumpur Lapindo ini menuntut Lapindo untuk bertanggungjawab atas insiden lumpur Lapindo yang masih terkait, serta masih berada dalam ruang lingkup operasional Lapindo. Menurut peneliti, sudah seharusnya Lapindo mengemban tanggung jawab dari kasus ini apabila dilihat dari sisi stakeholder theory, karena kebutuhan masyarakat akan tempat tinggal dan penghidupan yang layak menjadi terenggut, akibat dari kasus ini. Sehingga, sudah menjadi kewajiban Lapindo untuk melakukan upaya dalam memenuhi dan menyediakan kembali kepentingan stakeholder yang hilang tersebut.

Implementasi tanggung jawab sosial lingkungan dapat dikaitkan dengan kasus semburan lumpur Lapindo, dan apabila di kemudian hari dapat dibuktikan bahwa penyebabnya lebih cenderung mengarah pada kesalahan pengeboran, maka implementasi tanggung jawab sosial lingkungan Lapindo perlu dipertanyakan dan perlu untuk diperbaiki kembali. Bahwasanya memang terbukti bahwa lumpur Lapindo disebabkan oleh kesalahan pengeboran, maka menurut dugaan peneliti, pelaksanaan pengeboran tidak dilaksanakan dengan prinsip kehati-hatian. Untuk mendukung mengenai adanya potensi dugaan kejahatan korporasi, peneliti merujuk pada laporan ringkasan eksekutif hasil audit (Badan Pemeriksa Keuangan,2007), yang menyatakan 
bahwa tidak dipasangnya casing saat pengeboran merupakan pemicu terjadinya semburan lumpur.

Menurut (Broni,2009) dalam (Velentzas dan Broni,2010), tanggung jawab etika memperhatikan ekspektasi masyarakat yang melebihi hukum, contohnya seperti ekspektasi bahwa organisasi akan melakukan urusan mereka dalam cara yang jujur dan semestinya. Menurut peneliti, tanggung jawab untuk mengimplementasikan etika dalam operasional bisnis merupakan ekspektasi dari para stakeholder kepada setiap korporasi.Untuk mengimplementasikan etika tersebut dalam korporasi, digunakanlah mekanisme tata kelola perusahaan yang baik yang mana di dalam mekanisme tata kelola perusahaan yang baik, terdapat prinsip-prinsip yang mendukung penerapan etika, seperti prinsip responsibility dan accountability.

Menurut (Wibisono, 2007), prinsip responsibility yang terdapat pada good corporate governance (GCG) mempunyai kekerabatan paling dekat dengan CSR. Melalui penerapan prinsip ini diharapkan perusahaan dapat menyadari bahwa dalam kegiatan operasionalnya seringkali ia menghasilkan dampak eksternal yang harus ditanggung oleh stakeholders.Menurut peneliti, tanggung jawab sosial dan lingkungan seharusnya dilakukan pada kegiatan operasional Lapindo sehari-hari.

Akan tetapi, jika kita melihat dari perspektif dugaan penyebab lumpur lapindo adalah dapat diakibatkan oleh kesalahan pengeboran, seperti dugaan bahwa casing yang belum dipasang hingga kedalaman tertentu di sumur Banjarpanji, menunjukkan bahwa kegiatan pengeboran diduga tidak dilakukan dengan prinsip kehati-hatian, karena prinsip kehati-hatian merupakan bentuk tanggung jawab perusahaan kepada masyarakat dan lingkungan alam agar aktivitas dan kegiatan operasional bisnis perusahaan tidak mengganggu maupun menimbulkan dampak negatif bagi masyarakat sekitar, lingkungan alam, maupun bagi Negara. Oleh karena itu, prinsip responsibility yang diduga diabaikan ini dapat dikatakan sebagai pemicu munculnya implikasi dugaan kejahatan korporasi yang dilakukan Lapindo.

Adapun kasus lumpur Lapindo telah ditetapkan sebagai bencana alam dan penyebabnya dikatakan sebagai akibat dari aktivitas 68eismic yang berkaitan dengan gempa di Yogyakarta, bukan berarti bahwa prinsip responsibility dalam tata kelola perusahaan tidak diperhatikan lagi. Lapindo hendaknya tetap mengimplementasikan tanggung jawab sosial lingkungan secara jangka panjang pada wilayah operasionalnya yang lain, untuk menghindari risiko terulangnya kejadian seperti lumpur Lapindo ini. Selain itu, meskipun telah ditetapkan sebagai bencana alam nasional dan tanggung jawab telah diambil alih oleh Pemerintah, bukan berarti Lapindo "lepas tangan" begitu saja.

Jika dihubungkan dengan prinsip accountability, Lapindo dapat dikatakan tidak sepenuhnya mengimplementasikan prinsip tersebut didalam tata kelola perusahaan.Akuntabilitas menekankan bahwa terdapat kejelasan mekanisme pertanggungjawaban perusahaan kepada para stakeholder dan shareholdernya. Dalam penelitian ini, Lapindo selaku perusahaan atau korporasi yang memiliki kuasa dan dipercaya oleh Pemerintah untuk mengelola sumber daya alam tidak terbarukan sudah sewajibnya untuk selalu dapat mempertanggungjawabkan serta menjelaskan hal-hal yang berkaitan dengan bagaimana cara perusahaan melakukan tata kelola dalam aktivitas sehari-hari, serta memberi laporan kepada stakeholder yakni khususnya pada masyarakat dan negara. Prinsip accountability tidak diterapkan sepenuhnya karena Lapindo tidak 
mempertanggungjawabkan kinerja dan aktivitas perusahaan kepada stakeholder karena sebelum kejadian lumpur Lapindo ini, tidak dibuat maupun tidak dirilis laporan keberlanjutan.

Menurut peneliti, pembuatan laporan dengan judul "Laporan Sosial Dampak Gunung Berapi Lapindo (LUSI Report)" bukan merupakan bentuk accountability perusahaan kepada masyarakat sebagai stakeholder.Peneliti dapat mengatakan demikiankarena laporan tersebut tidak mempertanggungjelaskan aktivitas dan kinerja perusahaan pada periode sebelumnya, sebelum lumpur Lapindo terjadi, karena laporan tersebut seakan dibuat secara reaktif, yakni saat setelah terjadinya kasus lumpur Lapindo. Sehingga, laporan tersebut dapat dikatakan dibuat bukan dengan kesadaran dari entitas tersebut.

\section{Kesimpulan}

Implementasi aktivitas tanggung jawab sosial dan lingkungan oleh PT Lapindo Brantas Inc. yaitu melalui pengelolaan dampak lingkungan yang berfokus pada pengelolaan limbah sisa kegiatan operasi, dan pelaksanaan program pengembangan masyarakat yang diantaranya meliputi pemberdayaan ekonomi masyarakat, perbaikan infrastruktur, dan pembangunan fasilitas umum dan sosial.

Meninjau dari salah satu dugaan penyebab lumpur Lapindo, yakni akibat kesalahan manusia saat pengeboran, potensi munculnya dugaan kejahatan korporasi yang dilakukan oleh Lapindo adalah ketika terjadi semburan lumpur panas di areal dekat lokasi sumur BanjarPanji - 1 di Desa Renokenongo, Kecamatan Porong, Kabupaten Sidoarjo, pada tanggal 29 Mei 2006 yang mengakibatkan setidaknya 12 desa tenggelam serta 40-60 ribu penduduk harus mengungsi.

Karakteristik dugaan kejahatan korporasi yang terdapat pada kasus yang dialami PT Lapindo Brantas Inc. yaitu complexity, diffusion of victimization, diffusion of responsibility, lenient sanctions, dan difficult to detect and prosecute masing-masing mendukung konsep kejahatan korporasi yang telah dipaparkan sebelumnya pada kerangka teoritis. Lalu kemudian, implementasi tanggung jawab sosial dan lingkungan yang baik sangatlah penting bagi suatu perusahaan karena berfungsi sebagai dasar dalam pengambilan keputusan bisnis secara jangka panjang bagi perusahaan dan juga menghindarkan perusahaan dari potensi untuk terlibat dalam kejahatan korporasi.

Dalam suatu kasus dugaan kejahatan korporasi yang terjadi pada suatu perusahaan dapat dikaitkan dengan pelaksanaan tata kelola dari perusahaan tersebut, dan jika terdapat prinsipprinsip tata kelola serta aspek etika bisnis yang dilanggar oleh perusahaan, kemungkinannya akan sangat besar bagi korporasi tersebut untuk bersinggungan maupun berpotensi terlibat dengan kejahatan korporasi. Berdasarkan kesimpulan peneliti, Lapindo telah melanggar beberapa prinsip tata kelola yakni accountability, dan responsibility, serta melanggar etika bisnis, maka Lapindo dapat berpotensi diduga telah melakukan suatu kejahatan korporasi.

Dari sisi akuntansi, secara luas manajemen perusahaan berperan sebagai pengelola, yang memiliki tanggung jawab tidak hanya kepada shareholder saja, tetapi juga kepada stakeholder.Sehingga, apabila manajemen melakukan suatu tindakan baik yang disengaja maupun tidak, dapat berpotensi untuk bersinggungan dengan kejahatan korporasi. Implikasi lebih jauhnya, kondisi yang ada pada Indonesia saat ini adalah mekanisme penegakan hukum yang ada kurang baik, sehingga tidak memiliki kejelasan pada proses penegakan hukumnya. Akibat dari ketidakjelasan proses penegakan hukum bagi kejahatan korporasi di Indonesia, suatu kasus menjadi rentan dikriminalisasi. Agar tidak mudah dikriminalisasi dan supaya tidak selalu terjadi, diperlukan adanya proses 
penegakan hukum yang jelas dan transparansi.

\section{Daftar Pustaka}

Agestu, I.

2014.TigaPuluhTahunUsaiTraged $i$, Korban Bhopal MintaKeadilan. http://www.cnnindonesia.com/inte rnasional/20141204020243-11315720/tiga-puluh-tahun-usaitragedi-korban-bhopal-mintakeadilan/ (diunduhtanggal 19 Mei 2016)

Ali, M. 2008. KejahatanKorporasi: KajianRelevansiSanksiTindakanB agiPenanggulanganKejahatanKor porasi,

ArtiBumiIntaran:Yogyakarta.

Aras, G., dan D. Crowther. 2008. Governance and Sustainability; An Investigation Into the Relationship Between Corporate Governance and Corporate Sustainability. Management Decision, Vol.46(3): 433-448.

BadanPemeriksaKeuangan. 2007. RingkasanEksekutifLaporanPemer iksaanatasPenangananSemburan Lumpur Sidoarjo:2-8. http://www.environmentalauditing.org/portals/0/auditfiles/in donesia s hotmud.pdf.(diunduh 25 Oktober 2015).

Bakrie. 2014.

LaporanDampakSosialGunungBer api Lumpur Lapindo. http://www.environmentalauditing.org/portals/0/auditfiles/in donesia_s_hotmud.pdf (diunduh 25 Oktober 2015).

Barret, P. 2014. BP's Lessons in Playing Nasty or Nicehttp://www.bloomberg.com/n ews/articles/2014-09-11/lessonsfrom-bps-growing-gulf-spillpayout(diunduhtanggal 16 Januari 2016).

Bergin, T. 2010. Analysis: $B P P R$ blunders carry high political cost. http://www.reuters.com/article/us-oilspill-bp-pr-idUSTRE65S3JL20100629 (diunduhtanggal 11 Mei 2016).

British Petroleum. 2016. Managing Our Environmental and Social Impacts.

http://www.bp.com/en/global/corp orate/sustainability/how-weoperate/managing-ourenvironmental-and-socialimpacts.html (diunduh 11 Januari 2016).

British Petroleum. 2010. Annual Report and Form 20-F. http://www.bp.com/content/dam/b $\mathrm{p} / \mathrm{pdf} /$ investors/bp-annual-reportand-form-20f-2010.pdf (diunduh 30 Maret 2016).

Davies, J.R., M. Brumm, M. Manga, R. Rubiandini, R. Swarbrick, M. Tingay. 2008. The East Java Mud Volcano (2006 to present) : An earthquake or drilling trigger?. Earth and Planetary Science, 272:637.

detikNews. 2004 KorbanPencemaranMerkuriPantaiB uyatLaporkeDepkes.

http://news.detik.com/berita/1780

23/korban-pencemaran-merkuripantai-buyat-lapor-ke-depkes (diunduhtanggal 18 Mei 2016).

detikNews. 2010. Tim IlmuwanInggris: PengeboranLapindoBrantasPicuSem buran

Lumpur.http://news.detik.com/berit a/1298498/tim-ilmuwan-inggrispengeboran-lapindo-brantas-picusemburan-lumpur(diunduhtanggal 19 Februari 2016).

detikNews. 2007. PoldaJatimTak Akan TutupKasusLapindo. http://news.detik.com/berita/7563 23/polda-jatim-tak-akan-tutupkasus-lapindo(diunduhtanggal 13 Januari 2016).

Fisk, and L. Calkins. 2013. BP Gulf of Mexico Spill, From Disaster to Trial: Timeline. http://www.bloomberg.com/news/ articles/2013-02-25/bp-gulf-ofmexico-spill-from-disaster-to- 
trial-timeline(diunduhtanggal 29Maret 2016).

Fisk, Calkins, danFeeley. 2014. BP Found Grossly Negligent in 2010 Gulf of Mexico Oil Spill. http://www.bloomberg.com/news/ articles/2014-09-04/bp-foundgrossly-negligent-in-2010-gulf-ofmexico-spill(diunduhtanggal 16 Januari 2016).

Fontaine, M. 2013. Corporate Social Responsibility and Sustainability: The New Bottom Line?.International Journal of Business and Social Science,Vol.4(4): 110-114.

Hays, K. 2015.Factbox: BP's $\$ 18.7$ billion oil spill deal by the numbers.http://www.reuters.com/a rticle/us-bp-gulfmexicosettlement-numbers-factidUSKCN0PC22K20150703?mod $=$ related\&channelName $=$ domestic News(diunduhtanggal 10 Februari 2016).

Hutauruk, R.H. 2014. PenanggulanganKejahatanKorpor asiMelaluiPendekatanRestoratifSu atuTerobosanHukum, SinarGrafika: Jakarta.

KomisiNasionalHakAsasiManusia. 2011.

Ringkasaneksekutifhasilpenyelidik antim ad hoc penyelidikanpelanggaran HAM beratperistiwalumpurpanas lapindo: 1-

30.http://www.komnasham.go.id/s ites/default/files/dok-

publikasi/Ringkasan\%20eksekutif \%20lapindo.pdf.(diunduh 9 Februari 2016).

Kondracki, L. and N. Wellman. 2002. Content Analysis: Review of Methods and Their Applications in Nutrition Education. Journal of Nutrition Education and Behaviour, Vol.34(4): 224.

Kramer, R.C. 1984. Corporate Criminality: The Development of an Idea. In E Hochstedler (Ed.), Corporations as criminals. Sage: Beverly Hills,CA, pp.13-38.
Kurniawan, I. 2013. 25 Perusahaan MigasTerbesar di Dunia.http://bisnis.news.viva.co.id /news/read/420151-25perusahaan-migas-terbesar-didunia (diunduh 17 Mei 2016).

LapindoBrantas Inc. 2016.Responsibilities-

Health,Safety, and

Environment.http://lapindobrantas.co.id/id/responsibilities/he alth-safety-environment/ (diunduh 12 Februari 2016).

Lawrence, W., dan J. Weber. 2008. Business and Society: Stakeholders, Ethics, Public Policy, $12^{\text {th }}$ ed.McGraw-Hill/Irwin: New York.

Mattera, P. 2015. 17 of the Worst Corporate Crimes of 2015.The ongoing corporate crime wave shows no signs of abating.http://www.alternet.org/ec onomy/17-worst-corporatecrimes-2015 (diunduh 19 Mei 2016).

NRDC. 2015. Summary of Information Concerning the Ecological and Economic Impacts of the BP Deepwater Horizon Oil Spill Disaster https://www.nrdc.org/sites/default/ files/gulfspill-impacts-summaryIP.pdf(diunduh 20 Januari 2016).

OECD. 2015. G20/ OECD Principles of Corporate Governance. https://www.oecd.org/daf/ca/Corp orate-Governance-PrinciplesENG.pdf (diunduh 9 April 2016).

Setiyono $\mathrm{H}$. 2004. AnalisisViktimologidanPertanggu ngjawabanKorporasidalamHukum Pidana Indonesia, BayumediaPublishing:Malang.

Simpson, S. 2002. Corporate Crime,Law, and Social Control, Cambridge University Press: New York.

Suhartati. 2015. Pendekatan IntegrationOriented System DalamUpayaPenanggulanganKeja hatanKorporasi. PidatoIlmiah. Rapat Terbuka SenatUniversitas 
Surabaya dalamrangka Dies Natalis ke-47 Universitas Surabaya. 11 Maret. Surabaya.

Sukmana, Y. 2014. Ini 10 Perusahaan MinyakRaksasaDunia.

http://bisniskeuangan.kompas.com /read/2014/06/28/1242222/Ini.10.

Perusahaan.Raksasa.Minyak.Duni a(diunduhtanggal 17 Mei 2016).

Tejo, A. 2009. SP3 Lumpur Lapindo, KapoldaJatimTak Mau Disalahkan. http://news.okezone.com $/ \mathrm{read} / 200$ 9/08/14/1/248164/sp3-lumpurlapindo-kapolda-jatim-tak-maudisalahkan (diunduhtanggal 12 Februari 2016).

The Committee on the Financial Aspects of Corporate Governance. 1992.

The Financial Aspects of Corporate Governance. http://www.ecgi.org/codes/docum ents/cadbury.pdf (diunduh 22 April 2016).

Undang-UndangRepublik Indonesia Nomor 40 tahun 2007.Perseroan Terbatas. $16 \quad$ Agustus 2007.Lembaran Negara Republik Indonesia Tahun 2007 Nomor 106. Jakarta.

Undang-UndangRepublik Indonesia Nomor 23 tahun 1997.PengelolaanLingkunganHid up. 19 September 1997. Lembaran Negara Republik Indonesia Tahun 1997 Nomor 68. Jakarta.

Valmohammadi, C. 2013. Impact of corporate social responsibility practices on organizational performance: an ISO 26000 perspective. Social Responsibility Journal, Vol.10: 455-457.

Velentzas, J., dan B. Georgia. 2010. Ethical Dimensions in the conduct of business: Business ethics, Corporate Social Responsibility and The Law. The "Ethics in Business" as a sense of business ethics.International Conference on Applied Economics.795-

WCED. (1987). Our Common Future : The Brudtland Report.

Whitman, E. 2015. Exxon Valdez Oil Spill Anniversary: Effects, Facts, Pictures, Captain's Drinking Rumors. http://www.ibtimes.com/exxonvaldez-oil-spill-anniversaryeffects-facts-pictures-captainsdrinking-rumors$\underline{1856434}$ (diunduh tanggal $18 \mathrm{Mei}$ 2016).

Wibisono, $\quad$ Y. 2007. MembedahKonsepdanAplikasi $C S R$, Fascho Publishing: Gresik. 
